\title{
The Research Of Landless Peasants Social Risk Management Which Is Based On The Perspective Of Social Security
}

\author{
Ma Keji and Hu Liping \\ School of Public Management, Yunnan University of Economics and Finance, Kunming,, P.R. China, 650221 \\ (makeji2013@163.com)
}

\begin{abstract}
In recent years, the social risk problems caused by the process of expropriation farmers' land as government action, due to the land expropriation compensation, resettlement cost problems cannot be solved effectively, have caused widespread concern of government and society. Strengthening the social security system in pension, health care, employment, etc., can effectively resolve social risks of landless peasants.
\end{abstract}

Keywords: landless farmers; social security; risk management

\section{Introduction}

With the rapid development of industrialization and urbanization in China, the demand of the nonagricultural land is also growing. At the same time, big amount of agricultural land has been levied that leads farmers lost their land which they lived on it by generations. As the social security system is incomplete, the farmers who lost their land would lose the protection of their lives. Losing land is an inevitable social phenomenon during the process of a national socio-economic development and urbanization. A series of social conflicts which are aroused by land acquisition is increasing. And how to resolve the social conflicts has become an important issue for the whole society.

As the current situation of insufficient land resources, urban development and industrialization construction have created a great demand for non-agricultural land, On the contrary, the agricultural land will be inevitably reduced. The farmer-owned land will be gradually levied by the state until no land plan availably. We can simply put the part of peasants called "landless peasants". The compensation of landless peasants and collective is determined based on the land value, and the main basis of the law is the value of land in agricultural land. It means that the compensation to farmers only for the value of the land as agricultural usage, while considered value as non-agricultural land after the huge differential rent is unrelated to farmers. The core of this process, is the land value increased ten more times, hundreds more times, and the local government became the legal owner of the real differential income and lands, farmers were completely ruled out sharing of benefits. Moreover, farmers do not have any room for negotiation and bargaining during the land losing process. Therefore, it appeared so many disputes and collective petitions during the land acquisition process.

\section{The status quo of landless peasants social risk}

With the rapid development of social economy, the strength of collecting the collectively-owned land is growing, meanwhile the number of landless peasants is also increasing. According to the Ministry of Agriculture and the State Council Development Research Center statistics, from 1987 to 2001, the occupation of cultivated land for non-agricultural construction is up to 33946000 acres. It is predicted that from 2000-2030 the occupation of cultivated land will be more than 54500000 acres. At present, China has about 127 million landless peasants. And with the increasing rate of 200 million per year, there will be about 170 million landless peasants by 2030 . 
Land is not only the foundation for peasants to settle down, but also the income which can maintain a reliable and stable life. Once the land has been imposed, the farmers will have to face a serious of serious problems, such as employment and social security. Because of this, their life will be affected seriously.

\subsection{The risk of poverty which is brought by the} low compensation costs

Due to the non-market and the low compensation of land acquisition, farmers' lives become poorer and poorer. The compensation is the core issue of land acquisition, the international common practice is to compensate in accordance with the market price. However, the standard which is set by the "Land Management Law" in our country is that: the land compensation fee is 6-10 times of the average annual output value in the first three years of the expropriated land., while the resettlement subsidy is 4-6 times. But the resettlement subsidies of each hectare of land should not be more than 15 times of the first three years' average annual output value of the requisitioned land. This is a policy price which is totally unrelated to a market economy, and is too far from the market price of the land and the economic expectation of farmers. The compensation fee of land acquisition includes land compensation, resettlement subsidies and the compensation fee of attachments and young crops on the land, we can see the current project of land acquisition only includes the direct losses, does not include indirect losses. And it rarely takes into account to protect the interests of farmers so that the peasant is very discontent with the behavior of government.

\subsection{The risk of social equity which is brought by} the low resettlement costs

The resettlement fees of land acquisition is too low, and the means of distribution has remain confused. The means of land compensation in rural mainly adopts a one-time cash compensation, but the number is far below the cost of land expropriation compensation even the amount of compensation is large different across the country. And a few land acquisition compensation is distributed to the landless peasants after retaining by the township and village. Township government as the grassroots organization, is not the owners of the rural land, but it is still get a part of land compensation in distribution. The allocation and use of compensation is also not the same, which resulting in confusion. It is used for the collective, or just part of it for landless farmers.

\subsection{The risk of social security which is brought by settling singly}

Currently, our peasantspeasants are still relying on the land heavily, most of them are diversified in terms of employment. Nevertheless, the land is still the basic living sources for those peasantspeasants who with lower educational level, even if some of the rural labors have achieved the transfer of nonagricultural. In addition, in the situation of the social security system is extremely imperfect the land is also shouldering the basic social function of insuring peasants' lives. Current land expropriation compensation mechanism ignores the employment characteristics of farmers and social security function, it just implements a one-time and low amount of economic compensation simply. 


\section{The path to resolve social risks of landless peasants by using social security system}

Landless peasant is a transitional population between the farmers and the citizens. Establishing an completed social security system plays a crucial and related role for landless peasants during the transition from the rural to urban, which solves the worries of farmers to give up land fundamentally. In the process of land losing, the rural collective economy gained compensation and resettlement fees, and the government also received a huge amount of land income from the transfer. They should have the ability to provide social security for the landless peasants. Government can seize the opportunity of urbanization, transferring the rural surplus labors to urban and developing the tertiary industry to increase farmers' incomes, get rid of poverty and other problems. Therefore, establishing the social security system for landless peasants is the breakthrough to combine rural and urban social security system. It contributes to improve the integrity of the social security system, help the government to solve the "three rural issues", resolve social risks of landless peasants, and realize the goal of socialistic harmonious society.

\subsection{The lowest social security}

The lowest social security is to protect the population, who are living temporarily or permanently less than the national minimum standard. From the legal principle, the right of the lowest social security, is enjoyed by all citizens. It must establish a lowest social security for landless farmers, who are a transitional group between farmers and citizens, because they are neither entitled to the protection of land, nor entitled to social security for urban residents. Of course, we have to put some efforts to economic whenever the budget allowed. Such as, social relief items or funds can be converted to the lowest social security items or funds, all qualified landless peasants should bring into the lowest social security range in urban. All qualified landless peasants who remain rural should bring into the lowest social security. In order to protect people's basic living conditions, the living standard of the lowest social security should not be less than the local urban minimum living allowance.

\subsection{Social endowment insurance system}

The social security insurance about landless peasants is an common issue to farmers. Currently, traditional supporting models is still remain the model of family's support in the countryside. The risk of landless peasants' endowment problem is significantly increased, due to the lost land and the amount of single-child is increasing. Meanwhile, they will face a great risk in employment, because the landless peasants were limited by cultural qualities, and the pressure is increased invisibly. As a result, we must establish an endowment system for landless peasants. First of all, the "agricultural to non-agricultural" personnel landless peasants should establish an urban endowment system and the agricultural landless farmers should establish a system which is different from the urban. The details are as follows: implementing a one-time monetary resettlement for landless farmers under the age of 16; giving endowment insurance to the landless peasants who are in the working age during the land acquisition period and has participated in basic endowment insurance contributions over 15 years. For those who have not reached 15 years and should join the rural endowment insurance, the standard should be raised, at least not below the standard of urban endowment insurance. If farmers are over 60 
years old during the land acquisition period, we should give them a basic living allowance system, or provide a one-time cash compensation.

\subsection{Social health insurance system}

For the landless farmers, it is a heavy burden as higher and higher medical costs, especially for those who have serious illness. Therefore, we need to establish a health care system for landless peasants. On the one hand, we can incorporate all of the landless peasants into the urban medical insurance system, to realize the integration of rural and urban security model. On the other hand, the new rural cooperative health model can be implemented. The traditional medical cooperative model is inadequate in fund-raising, operation, management, etc. Therefore, we should overcome the shortcomings of the traditional system, strengthening fund management, special storage and special use about special fund to ensure that all cooperative medical fund and the interests will be used on farmers' medical aid. To explore the participate of farmers in supervision and long-term mechanism of democratic management, guarantee the farmers' right to know and supervise, promote comprehensive and healthy development of the new rural cooperative medical model, we should make scientific plan of reimbursement, implement cooperation medical review and reimbursement ways, and be based on the principle of management, supervision.

\subsection{To establish a system of unemployment} insurance and employment services and training

After their land lost, farmers will face huge employment risks due to the shortage of opportunities of education and training and the low cultural quality and labor skills. Most of them have already been in inferior position in competition for employment. We should establish unemployment insurance to promote employment. Referring to urban unemployment registration system, the land acquisition departments have to take handle of the unemployment insurances for the landless farmers who are in the working-age and participated in endowment security compliance, and the unemployment insurance benefits should be provided by the social security institutions. Meanwhile, all the landless peasants should be applied into urban employment services, and we must give them equal access to employment, credit and other support policies to urban laid-off workers. Let them free to enjoy the employment instruction and reemployment training policies. Then they will pay unemployment insurance fees after they have a job.

\subsection{To provide legal aid to landless peasants}

The Landless peasant is a vulnerable group, because they usually cannot protect their rights due to shortage of money and relevant legal knowledge when their rights are violated. Therefore, it should provide legal assistance to them, enable them to get closer to the law and use their own rights to safeguard their interests. Such as, the landless peasants should set a priority by establishing a green channel; the program should be simplified and the speed should be accelerated when the landless peasants apply for legal aid; the landless peasants, who have bad economic and the conditions of legal aid, attorney fees should be reduced or free reasonably.

\section{The conclusion}

For farmers who lost their land, they also lost a series of the rights and interests which are associated with it. The social security of landless peasants provides an opportunity for establishing an unified social security system as early as possible. The government exchanges the social security for land, and the farmers with land exchange it for social security. Exchanging the land for security is an effective way 
and an important means to achieve integration of urban and rural areas. In addition, it can help to accelerate the establishment of a unified national social security system, which is beneficial to the healthy development of the land market. After the development of exchanging the land for social security, peasants will be full employed and the industrial park will keep developing sustainably, along with this the strength of social security fund will be strengthened, and the accumulation of social security funds accelerated in potential. Establishing the social security system for landless peasants can not only enable them to acquire the basic right of existing and developing, but also can promote the sustainable development of harmonious society.

\section{References}

(1) Liu Xin. (2014). Social security of landless peasants under the city problems.Financial Community.2014,2.

(2) Xu Huijuan. (2013) Endowment security research about landless peasants during urbanization process. Academic Forum, 2013,11 .

(3) Xing Jingpeng.. (2013). Research of landless peasants' endowment security protection level under the background of urbanization. Economy and Management. 2013,11.

(4) Cai Xiaowei (2013) Research of social security legislation mode about landless peasants during urbanization - take sample as Zhejiang province. Zhejiang Finance. 2013,11.

(5) $\mathrm{Xu}$ Lin. (2013). Analysis about the establishment of social security system by the government for the landless peasants during urbanization. The Knowledge Economy. 2013,22 